Creative commons User License: CC BY-NC-ND

Abstracted by: EBSCOhost, Electronic Journals Service (EJS),

Google Scholar, Directory of Open Access Journals (DOAJ),

Journal Seek, Scientific Commons,

Food and Agricultural Organization (FAO), CABI and Scopus
Journal of Agricultural Extension

Vol. XX (X) XXXXXX, 20XX

ISSN(e): 24086851; ISSN(Print); 1119944X

http://journal.aesonnigeria.org

http://www.ajol.info/index.php/jae

Email: editorinchief@aesonnigeria.org

\title{
Adoption Level of IFAD Project Recommended Farming Practices among Smallholder Crop Farmers in Katsina State, Nigeria \\ http://dx.doi.org/10.4314/jae.v20i2.3
}

\author{
Abdullahi Alhaji Jamilu \\ National Agricultural Extension and Research Liaison Services, A.B.U Zaria \\ E-mail address: alhjamilu30@gmail.com Phone Number: 08028448193
}

Atala T. K.

Department of Agricultural Economics and Rural Sociology, A.B.U Zaria atalatk@yahoo.com Phone Number: 08084708505

\section{Akpoko J. G.}

Department of Agricultural Economics and Rural Sociology, A.B.U Zaria josephgamboakpoko@gmail.com Phone Number: 08033973686

\section{Sanni S. A.}

Department of Agricultural Economics and Rural Sociology, A.B.U Zaria adsanni@yahoo.com Phone Number: 08054558197

Haruna S. K.

National Agricultural Extension and Research Liaison Services, A.B.U Zaria

salisukura@gmail.com Phone Number: 08026929746

\section{Abstract}

This study assessed the adoption level of IFAD-CBARDP recommended farming practices among smallholder crop farmers in Katsina State. Data for the study were obtained by the use of structured questionnaire. Multistage sampling procedure was employed to select 349 respondents. Descriptive statistics were used to analyze the data. The result revealed that the mean age of the participating farmers was 46years, $91 \%$ were males, and a mean farm size of 3.21 hectares. The study also revealed that $87.2 \%, 83 \%$ and $82.73 \%$ of the respondents respectively adopted the use of recommended fertilizer, method and dosage of fertilizer application and the use of seed dressing chemicals. The result further showed that $16.9 \%, 15.2 \%$ and $14.6 \%$ of the respondents respectively identified low counterpart funding, untimely disbursement of funds and inadequate mobility of extension staff as the major constraints to the effective implementation of the programme. Generally, there was a high level of adoption of the recommended farming practices among the participating farmers in the study area. The study recommends that the funding of the project should be centrally coordinated, with contributions made by all the three tiers of government.

Keywords: Adoption level, IFAD-CBARDP, Smallholder Farmers. 
Creative commons User License: CC BY-NC-ND

Abstracted by: EBSCOhost, Electronic Journals Service (EJS),

Google Scholar, Directory of Open Access Journals (DOAJ),

Journal Seek, Scientific Commons,

Food and Agricultural Organization (FAO), CABI and Scopus
Journal of Agricultural Extension

Vol. XX (X) XXXXXX, 20XX

ISSN(e): 24086851; ISSN(Print); 1119944X

http://journal.aesonnigeria.org

http://www.ajol.info/index.php/jae

Email: editorinchief@aesonnigeria.org

\section{Introduction}

Agricultural Development has been a major concern to most developing countries within the last two decades (Stella, 2012). Rural Development is the bedrock of agricultural development in developing countries (including Nigeria) where most farmers are involved in subsistence agricultural practice. Idachaba (2000) defined rural development as a means of providing basic amenities, infrastructure, improved agricultural productivity, extension services and empowerment generation for the rural dwellers. Banji, O., Adisa, and Esther, O. (2011) defined rural development as the improvement of the living standards of the low-income population living in rural areas to a self-sustaining basis through transformation of socio-spatial features of their productive activities. Most of the farmers in Katsina State are smallholder farmers that depend mostly on agriculture for their livelihoods. They rely on income from this occupation to finance their investments and domestic needs. Income from agriculture also affects the savings ability of the farmers, which invariably determines their ability to increase their scale of production. Also, the income generated from agriculture by the smallholder farmers affect their ability to provide their children with formal education and training, which will enhance their ability to respond to innovation and adopting them. Smallholder agriculture is presently a key sustainer of the majority of the world's poorest people, so the dynamics of smallholder agriculture ought to be a central question for research and debates about development, Jonathan (2002). Babatunde (2006) reported that the concern over increasing poverty levels especially in the developing countries such as Nigeria and the need for its alleviation as a means of improving the standard of living of the people has led to the conceptualization and implementation of various targeted poverty alleviation programmes worldwide. Among which are the Agricultural Development Project (ADP), River Basin and Rural Development Authorities (RBRDA), Extension Programmes such as the Agricultural Transformation Agenda (ATA), Agricultural Extension Transformation Agenda (AETA) and the Establishment of Agricultural Research Institutes. Others include International Fund for Agricultural DevelopmentCommunity Based Agriculture and Rural Development Programme (IFAD-CBARDP), 
Creative commons User License: CC BY-NC-ND

Abstracted by: EBSCOhost, Electronic Journals Service (EJS),

Google Scholar, Directory of Open Access Journals (DOAJ),

Journal Seek, Scientific Commons,

Food and Agricultural Organization (FAO), CABI and Scopus
Journal of Agricultural Extension

Vol. XX (X) XXXXXX, 20XX

ISSN(e): 24086851; ISSN(Print); 1119944X

http://journal.aesonnigeria.org

http://www.ajol.info/index.php/jae

Email: editorinchief@aesonnigeria.org

United Nation Development Programme (UNDP) and the African Development Bank (AFDB).

The International Fund for Agricultural Development Community Based Agriculture and Rural Development Programme (IFAD-CBARDP) was an integrated agriculture and rural development programme. The programme was launched on $31^{\text {st }}$ January 2003 with a completion date of $31^{\text {st }}$ march 2013 in eight states of northern Nigerian where poverty is widespread, the States include: Jigawa, Kano, Katsina, Kebbi, Sokoto and Zamfara in the north-west, and Borno and Yobe in the north-east (Bukar, 2005). The broad objective of the programme is to help the most vulnerable groups improve their incomes and living conditions.

Specifically, the programme objectives were to:

i. improve the livelihoods and living conditions of the rural poor with emphasis on women and other vulnerable groups;

ii. empowering the poor rural communities to enable them identify their needs, implement a broad range of agricultural and rural development (ARD) initiatives, and

iii. institutionalise and internalise community-driven development (CDD) into government policies and procedures.

The programme targets a large section of the rural population, especially women, landless people, nomadic pastoralists and small-scale farmers, and those with only marginal lands. It was designed to empower these groups to participate in development activities. Specifically, the programme works to:

- Promote awareness and build the capacity of public and private-sector service providers to respond to the needs of poor rural women and men

- Empower poor communities to manage their own development and support vulnerable groups

- Improve agricultural practices, resolve conflicts between farmers and pastoralists, and intensify crop and livestock production 
Creative commons User License: CC BY-NC-ND

Abstracted by: EBSCOhost, Electronic Journals Service (EJS),

Google Scholar, Directory of Open Access Journals (DOAJ),

Journal Seek, Scientific Commons,

Food and Agricultural Organization (FAO), CABI and Scopus
Journal of Agricultural Extension

Vol. XX (X) XXXXXX, 20XX

ISSN(e): 24086851; ISSN(Print); 1119944X

http://journal.aesonnigeria.org

http://www.ajol.info/index.php/jae

Email: editorinchief@aesonnigeria.org

- Develop or upgrade safe water supplies, environmental sanitation, irrigation, and health and education facilities

The Nigerian Government and IFAD have spent huge sum of money over the years to finance agricultural development through the adoption of Community Based Agriculture and Rural Development Programme (CBARDP) development strategy in the programme areas. Despite this, poverty seems to persist among most of the rural families in the study area. It is on this basis that this paper aimed at examining the adoption level of IFAD- Community Based Agriculture and Rural Development Project among smallholder crop farmers in Katsina State. The specific objectives of the study were to:

i. describe the socio-economic characteristics of the smallholder crop farmers in the study area;

ii. determine the level of adoption of IFAD-CBARDP recommended farming practices among smallholder crop farmers;

iii. identify the major constraints to the implementation of the programme in the study area.

\section{Methodology}

This study was conducted in Katsina State, one of the 36 States in Nigeria. The State lies between latitude $11^{\circ} 7^{\prime}$ and $13^{\circ} 22^{\prime}$ North and longitude $6^{\circ} 52^{\prime}$ and $9^{\circ} 2^{\prime}$ East of the Equator. It is situated within the Sahel-Sudan agro ecological zone of Nigeria. The National population census of 2006 put Katsina State at 5,792,579 people. At $3.2 \%$ growth rate projection, by 2013 when data were collected, Katsina State's population was expected to have increased to about $7,223,346$ people. The number of farmer's families is 882,692 constituting $12.22 \%$ of the total population (NPC, 2006). Data for the study were obtained by the use of structured questionnaire. Multistage sampling procedure was employed to select the respondents. The first stage involved the selection of the 12 participating LGAs from the 34 LGAs in the State; the second stage involved purposive sampling to select one village area that had the highest participating farmers out of the three participating villages in each 
Creative commons User License: CC BY-NC-ND

Abstracted by: EBSCOhost, Electronic Journals Service (EJS),

Google Scholar, Directory of Open Access Journals (DOAJ),

Journal Seek, Scientific Commons,

Food and Agricultural Organization (FAO), CABI and Scopus
Journal of Agricultural Extension

Vol. XX (X) XXXXXX, 20XX

ISSN(e): 24086851; ISSN(Print); 1119944X

http://journal.aesonnigeria.org

http://www.ajol.info/index.php/jae

Email: editorinchief@aesonnigeria.org

Local Government Area. The third stage involved the use of systematic random sampling technique to select twelve per cent (12\%) from the sample frame of 2,894 participating farmers from the selected villages. This gave a total of three hundred and forty-nine (349) participating farmers from the twelve participating village areas (Table 1). In addition, 3 IFAD-CBARDP officials were randomly selected from each of the 12 LGAs. Descriptive statistics such as percentages, means and ranking were used to analyze the data.

\section{Table 1: Sampling design}

LGA

\begin{tabular}{|c|c|c|c|}
\hline & $\begin{array}{l}\text { Purposively } \\
\text { selected } \\
\text { Participating } \\
\text { Villages }\end{array}$ & $\begin{array}{l}\text { Population } \\
\text { size of } \\
\text { Participating } \\
\text { Farmers }\end{array}$ & $\begin{array}{l}\text { Randomly } \\
\text { selected } \\
\text { Participating } \\
\text { farmers }(12 \%)\end{array}$ \\
\hline Danja & Kahutu & 492 & 59 \\
\hline Kurfi & Rawayau & 280 & 34 \\
\hline Musawa & Tsabe & 220 & 26 \\
\hline Bakori & Jargaba & 180 & 22 \\
\hline \multirow[t]{2}{*}{ Baure } & Hurtumi & 135 & 16 \\
\hline & Yangora & 171 & 21 \\
\hline \multicolumn{4}{|l|}{ Bindawa } \\
\hline Dutsi & Karawa & 172 & 21 \\
\hline Jibia & Daga & 125 & 15 \\
\hline Kaita & Baawa & 415 & 50 \\
\hline \multirow[t]{2}{*}{ Batsari } & Yauyau & 293 & 35 \\
\hline & Yanshantuna & 165 & 20 \\
\hline \multicolumn{4}{|l|}{ Dutsinma } \\
\hline Kusada & Kofa & 246 & 30 \\
\hline Total & & 2894 & 349 \\
\hline
\end{tabular}

Source: Field Survey 2013 
Creative commons User License: CC BY-NC-ND

Abstracted by: EBSCOhost, Electronic Journals Service (EJS),

Google Scholar, Directory of Open Access Journals (DOAJ),

Journal Seek, Scientific Commons,

Food and Agricultural Organization (FAO), CABI and Scopus
Journal of Agricultural Extension

Vol. XX (X) XXXXXX, 20XX

ISSN(e): 24086851; ISSN(Print); 1119944X

http://journal.aesonnigeria.org

http://www.ajol.info/index.php/jae

Email: editorinchief@aesonnigeria.org

\section{Results and Discussion}

\section{Socio-economic Characteristics of Respondents}

The result in Table 2 shows that $23 \%$ of the respondents were within the ages of 46 50 years, with a mean age of 46 years. The result implies that most of the respondents were of middle age; signifying that they were within the agricultural productive age range of 30-50 years quoted by Food and Agriculture Organisation (FAO, 2005). Also having a population that is middle aged implies that the understanding and utilization of the IFAD-CBARDP recommended agricultural production practices would be easier since middle aged people are expected to have acquired the least minimum level of formal education and are likely to be more inquisitive in finding more result oriented techniques of improving agricultural productivity. Also, findings revealed that the majority $(97.1 \%)$ of the respondents had one form of education or the other with only $2.9 \%$ of the respondents having no formal education. This implies that the majority of the farmers in the study area are literate and were aware of the importance of improved-inputs for increased agricultural productivity, which would facilitate the adoption of technologies promoted by the IFAD-CBARDP. Farinde, A.J., Ogunsumi, L.O., Omoyajowo, A.O, and Oyegbami, O. (2005) had identified literacy among other factors as a variable that positively influenced the use of improved agricultural inputs by farmers. It also supported the findings of Caswell, M., Fuglie, K., Ingram, C., Jans, S. and Kascak, C. (2001) who found that farmers' education creates a favourable mental attitude for acceptance and management of new practices.

The result further reveals that $85.7 \%$ of the respondents belong to cooperative associations. This implies that the farmers under the project were properly organized for easy access to subsidy and credit facilities. This is an indication that the more farmers participate in cooperative societies, the better the idea, knowledge and benefits derived from among members. The result also revealed that the average farm size for the respondents was 3.21 hectares. The result implies that the farmers fall within the range of smallholder farmers. This supported the findings of Salau, E.S., Saingbe, N.D. and Garba, M. N. (2013) in a study of Agricultural Information 
Creative commons User License: CC BY-NC-ND

Abstracted by: EBSCOhost, Electronic Journals Service (EJS),

Google Scholar, Directory of Open Access Journals (DOAJ),

Journal Seek, Scientific Commons,

Food and Agricultural Organization (FAO), CABI and Scopus

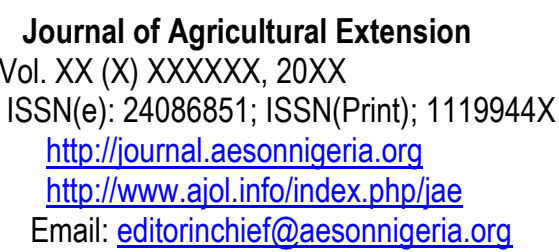

needs of smallholder farmers in Central Agricultural Zones of Nasarawa State which revealed that the majority $(68 \%)$ of the respondents had farm sizes ranging between 1- 5ha. Size of farmland is expected to aid the adoption of new technologies by farmers because farmers that lack enough farmland cannot sacrifice their land for trials of new technology. The result further shows that the mean household size for the respondents was 10 persons per household. This implies that the respondents had a relatively large household size, which has an implication for labour availability for farm work. The result agrees with the findings of Chianu and Tsuji (2004) who reported that farmers with large household size are more likely to adopt some soil improvement technology due to sufficient labour. The findings also tallied with the findings of the International Fund for Agricultural Development (IFAD) conducted in the area (2001) that the majority of the farmers in the area have large household size. It implies that the farmers in the study area have large house holdings. This also suggests that the respondent had adequate family labour to cultivate large farms. 
Creative commons User License: CC BY-NC-ND

Abstracted by: EBSCOhost, Electronic Journals Service (EJS),

Google Scholar, Directory of Open Access Journals (DOAJ),

Journal Seek, Scientific Commons,

Food and Agricultural Organization (FAO), CABI and Scopus
Journal of Agricultural Extension

Vol. XX (X) XXXXXX, 20XX

ISSN(e): 24086851; ISSN(Print); 1119944X

http://journal.aesonnigeria.org

http://www.ajol.info/index.php/jae

Email: editorinchief@aesonnigeria.org

Table 2: Socio-economic characteristics of sampled farmers

Variables Percentage $(n=349)$

Mean (M)

Age in year

$21-25$

2.3

$26-30$

6.4

$31-35$

7.9

$36-40$

18.1

46

$41-45$

16.9

$46-50$

23.0

$51-55$

25.4

Level of Education

No formal education

Adult education

5.0

Primary

62.6

Secondary

23.7

Tertiary

5.8

Membership of cooperatives

Members

85.7

Non-members

14.3

Farm Size in (ha)

$0.5-1.0$

35.6

$1.1-1.5$

3.8

$1.6-2.0$

30.3

$2.1-2.5$

1.8

$2.6-3.0$

1.2

$3.1-3.5$

13.2

$3.6-4.0$

14.1

Household Size

$1-5$

32.1

$6-10$

32.9

$11-15$

16.3

10

$16-20$

11.7

$21-25$

5.0

$26-30$

1.7

$31>$

0.3 
Creative commons User License: CC BY-NC-ND

Abstracted by: EBSCOhost, Electronic Journals Service (EJS),

Google Scholar, Directory of Open Access Journals (DOAJ),

Journal Seek, Scientific Commons,

Food and Agricultural Organization (FAO), CABI and Scopus
Journal of Agricultural Extension

Vol. XX (X) XXXXXX, 20XX

ISSN(e): 24086851; ISSN(Print); 1119944X

http://journal.aesonnigeria.org

http://www.ajol.info/index.php/jae

Email: editorinchief@aesonnigeria.org

\section{Level of Adoption of IFAD-Community Based Agriculture and Rural Development recommended practices}

Figure 1 shows the level of adoption of IFAD-Community Based Agricultural and Rural Development recommended practices among the participating farmers. The result showed that $75.97 \%$ of the respondents adopted the use of improved seed varieties, $82.75 \%$ adopted the use of seed dressing chemicals, $83.91 \%$ adopted the use of seed rate, $85.37 \%$ adopted the use of adequate plant spacing and $88.66 \%$ adopted the use of recommended fertilizer. Other recommendations adopted by the participating farmers include method and dosage of fertilizer application (83\%), timely planting (85\%), use of herbicides $(87.21 \%)$, timely harvesting $(89.92 \%)$ and proper storage (88.18\%). Generally, there was high level of adoption of the recommended production practices introduced to the farmers as shown below in figure 2. This high level of adoption supported Ganpat and Seepersad (1996) whose report shows that for a successful adoption of new technology, farmers must not only know about it, but must be able to follow the recommendations given. This implies that the farmer must have the knowledge before putting the recommendations into practice. The result also affirm the findings of Abdullahi, A. and Haruna U. (2011) whose findings showed that farmers adoption of technologies was impressive, with up to $76 \%$ and $58 \%$ for double and triple bagging respectively. Generally, there was a high level of adoption of the recommended farming practices among the participating farmers in the study area. 
Creative commons User License: CC BY-NC-ND

Abstracted by: EBSCOhost, Electronic Journals Service (EJS),

Google Scholar, Directory of Open Access Journals (DOAJ),

Journal Seek, Scientific Commons,

Food and Agricultural Organization (FAO), CABI and Scopus
Journal of Agricultural Extension

Vol. XX (X) XXXXXX, 20XX

ISSN(e): 24086851; ISSN(Print); 1119944X

http://journal.aesonnigeria.org

http://www.ajol.info/index.php/iae

Email: editorinchief@aesonnigeria.org

Level of Adoption of Technology

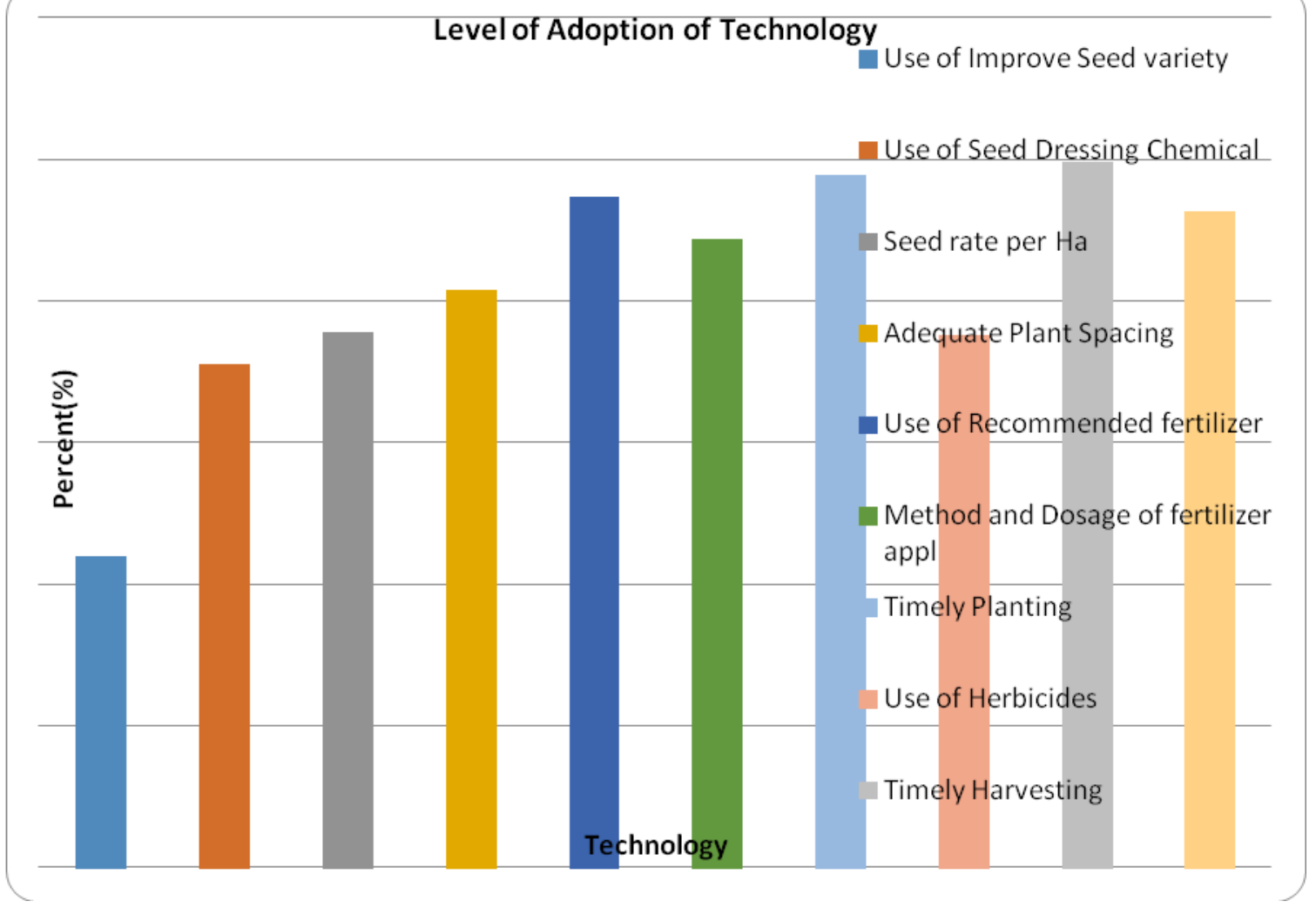

Fig. 1: Level of adoption of IFAD-CBARDP recommended practices

\section{Constraints to the Implementation of IFAD-CBARDP Programme}

The result in Table 3 shows that $16.9 \%$ of the respondents (IFAD-CBARDP) officials indicated low counterpart funding from the State and LGAs as the major problem constraining the implementation of the project. This has seriously affected the implementation of the programme in the sense that it caused delays in carrying out of some projects. This agreed with the findings of Abubakar (2011) who reported constraint to extension services of the ADPs was poor funding. Fund allocation from State government was found to be grossly inadequate and often disburse late. This low funding in addition to other factors led to the ADPs inability to meet their required logistics for attending REFILS workshop on annual basis. Similarly, $15.2 \%$ of the respondent revealed that untimely disbursement of funds by the State and Local Government Areas constrained the effective implementation of the project in the study area. Agricultural activities are time bound and therefore require prompt disbursement of funds. This corroborated the findings of Umar, S., Musa, M.W. and Shuaibu, H. (2013) which noted that recent developments especially in issues of 
Creative commons User License: CC BY-NC-ND

Abstracted by: EBSCOhost, Electronic Journals Service (EJS),

Google Scholar, Directory of Open Access Journals (DOAJ),

Journal Seek, Scientific Commons,

Food and Agricultural Organization (FAO), CABI and Scopus
Journal of Agricultural Extension

Vol. XX (X) XXXXXX, 20XX

ISSN(e): 24086851; ISSN(Print); 1119944X

http://journal.aesonnigeria.org

http://www.ajol.info/index.php/jae

Email: editorinchief@aesonnigeria.org

funding call for a rethinking about the future of agricultural extension services in Nigeria. It also confirmed the findings of Inni and Dimetu (2013) who found untimely release of counterpart funds to be major constraints to participation in the Fadama III project. The result also supported the findings of Muhammad, I.Y., Muhammad, T.A. and Sarwar, M. (2010) and Agbamu (2011) who noted that the major problems in the execution of programmes by the Non-Governmental Organization (NGO) include lack of coordination and over dependence on foreign donors, limited community participation and lack of proper documentation of activities. Other factors that constrained the effective implementation of the programme in the state included inadequate mobility among the extension personnel with $14.6 \%$ and untimely distribution/high cost of inputs $13.2 \%$. Effective extension contact can be possible if the extension agents are mobile. This finding also tallied with the findings of Agbamu (2011) who identified inadequacy and instability of funding, poor logistic support for field staff among others to be the major problems of agricultural extension services in developing countries.

Table 3: Major constraints to implementation of IFAD-CBARDP

\begin{tabular}{lcc}
\hline Major constraints & $\%$ & Rank \\
\hline Low counterpart funding & 16.9 & $1^{\text {st }}$ \\
Untimely disbursement of funds & 15.2 & $2^{\text {nd }}$ \\
Inadequate mobility of extension personnel & 14.6 & $3^{\text {rd }}$ \\
Untimely distribution/high cost of inputs & 13.2 & $4^{\text {th }}$ \\
\hline
\end{tabular}

${ }^{\star}$ Multiple responses

\section{Conclusion and Recommendations}

The study found that most of the respondents had one form of education or the other, belong to cooperatives associations, and have spent many years in the cooperatives. This has facilitated the adoption of improved technologies promoted by The IFAD-Community Based Agricultural and Rural Development Project in the study area. The study also found that there was a high level of adoption of IFADCBARDP recommended practices among the farmers in the study area. It also found that low counterpart funding among other factors had constrained the 
Creative commons User License: CC BY-NC-ND

Abstracted by: EBSCOhost, Electronic Journals Service (EJS),

Google Scholar, Directory of Open Access Journals (DOAJ),

Journal Seek, Scientific Commons,

Food and Agricultural Organization (FAO), CABI and Scopus
Journal of Agricultural Extension

Vol. XX (X) XXXXXX, 20XX

ISSN(e): 24086851; ISSN(Print); 1119944X

http://journal.aesonnigeria.org

http://www.ajol.info/index.php/jae

Email: editorinchief@aesonnigeria.org

implementation of the project in the study area. The study recommends that the funding of the project should be centrally coordinated, with contributions made by all the three tiers of government. In addition, extension workers should be made mobile to ease the problem of transportation in accessing their clients.

\section{References}

Abdullahi, A. and Haruna U. (2011). Assessment of the Adoption of Hermetic [Airtight] Storage Technology of Cowpea in selected Local Government Areas of Kano State. Nigerian Journal of Agricultural extension. 16 (182): 41-46.

Abubakar, S. Z. (2011). Constraints to Effective and Sustainable Financing of Public Sector Agricultural Extension Delivery System in Nigeria. Nigerian journal of agricultural Extension. 16 (1): 1-13.

Babatunde, O. (2006). "Differential Poverty Reduction" Impact of Small-Scale Irrigated Development between its Beneficiaries and Non-beneficiaries in Nigeria. Technical Report on the Agropolis Award.

Banji, O., Adisa, and Esther, O. (2011). Women in Agriculture and Rural Development. In: Agricultural Extension in Nigeria. Agricultural Extension Society of Nigeria (AESON), Ilorin, Nigeria, PP 90-100.

Bukar, T. (2005). Critical Challenges and Problems of Effective Programme/Project Implementation. Paper presented in a Workshop for Western and Central Africa, Bamaco, Mali $8^{\text {th }}-11^{\text {th }}$ March.

Caswell, M., Fuglie, K., Ingram, C., Jans, S. and Kascak, C. (2001). Adoption of Agricultural Production Practices: Lessons learned from the U.S. Department of Agriculture Area Studies Project. U.S. Department of Agriculture, Resource Economics Division, Economic Research Service, Agriculture Economic Report No. 792, Washington, D.C.

Chianu, J.N. and Tsuji, H. (2004). Determinants of Farmers to Adopt or not to Adopt Inorganic Fertilizer in the Savannah of Northern Nigeria. Nutrient Cycling in Agro-eco system. Kluvert Academic Publication, Netherland, Pp. 293-304.

Farinde, A.J., Ogunsumi, L.O., Omoyajowo, A.O, and Oyegbami, O. (2005). Farmer Involvement in the Transfer of Cassava Technologies in South-west Nigeria. International journal of Applied Agriculture and Research, 1(1):13-24.

Food and Agriculture Organisation (FAO) (2005). AQUASTAT Database. http:/www.fao.org/waicent/faointo/agricult/ag/w/aquastat/site visited $21 / 01 / 2014$ 
Creative commons User License: CC BY-NC-ND

Abstracted by: EBSCOhost, Electronic Journals Service (EJS),

Google Scholar, Directory of Open Access Journals (DOAJ),

Journal Seek, Scientific Commons,

Food and Agricultural Organization (FAO), CABI and Scopus
Journal of Agricultural Extension

Vol. XX (X) XXXXXX, 20XX

ISSN(e): 24086851; ISSN(Print); 1119944X

http://journal.aesonnigeria.org

http://www.ajol.info/index.php/jae

Email: editorinchief@aesonnigeria.org

Ganpat, W. and Seepersad (1996). An Analysis of Linkages in a Rice Based Knowledge System in Trinidad. Education (AIAEF) held at Arlington, Virginia.

Idachaba, F.S. (2000). Desirable and Workable Agricultural Policies for Nigeria. University Press Ibadan, Nigeria. Pp. 3-9.

Innih, C.D. and Dimelu, M.U. (2013). Participation and Atitude of Beneficiaries to the third National Fadama Development Project in Kogi State, Nigeria. Journal of Agricultural Extension 17 (2) 64-76.

International Fund for Agricultural Development (IFAD) (2001). The Challenge of Ending Rural Poverty, Rural Poverty Report, Oxford University Press.

Jonathan, K. (2002). Agriculture and Rural Livelihoods; Is Globalisation Opening or Blocking Paths Out of Rural Poverty? Agricultural Research and Extension Network (AgREN), Network Paper No. 121, January 2002.

Agbamu J. U. (2011). Problems and Prospect of Agricultural Extension Services in Developing Countries. In: Agricultural Extension in Nigeria. Agricultural Extension Society of Nigeria AESON, Ilorin, Nigeria, Pp 216-229.

Muhammad, I.Y., Muhammad, T.A. and Sarwar, M. (2010). Issues and Problems of Non-Governmental Organisations (NGOs) Working for Literacy in Pakistan; International Journal of Academic Research. 2 (6): 1-5.

National Population Commission (2006). Population and Housing Census, Federal Republic of Nigeria Vol. 1.

Salau, E.S., Saingbe, N.D. and Garba, M. N. (2013). Agricultural Information Needs of Smallholder Farmers in Central Agricultural Zones of Nasarawa State. Journal of Agricultural Extension. 17 (2): 127-135.

Stella, O.O. (2012). Gender Issues in Agricultural Extension and Rural Development in Nigeria. In: Rural Development - Contemporary Issues and Practices; Intech Publishers. University Campus Step Rislavka Krautzeka Rjeka, Crotia.

Umar, S., Musa, M.W. and Shuaibu, H. (2013) Funding Agricultural Extension in Nigeria. Is Privatisation the way Forward? In: the Proceeding of the $18^{\text {th }}$ Annual National Conference of Agricultural Extension Society of Nigeria held at Nasarawa State. $18^{\text {th }}-23^{\text {rd }}$ April. 